\title{
Use of combination method (uterine sandwich technique) to control postpartum hemorrhage
}

\author{
Atmajit Singh Dhillon, Karminder Dhillon*
}

Department of Obstetrics and Gynecology, Command Hospital, Lucknow, Uttar Pradesh, India

Received: 26 April 2018

Accepted: 25 May 2018

\section{*Correspondence:}

Dr. Karminder Dhillon,

E-mail: bugidhillon6@gmail.com

Copyright: (C) the author(s), publisher and licensee Medip Academy. This is an open-access article distributed under the terms of the Creative Commons Attribution Non-Commercial License, which permits unrestricted non-commercial use, distribution, and reproduction in any medium, provided the original work is properly cited.

\section{ABSTRACT}

Background: Uterine atony is the most common cause (75\%-90\%) of primary postpartum hemorrhage (PPH) and Christopher B Lynch was the first to highlight the use of Uterine Compression Sutures (UCS) for the management of atonic PPH. In combination therapy, the (UCS) is combined with intrauterine balloon tamponade, known as (uterine sandwich), for combined external as well as internal compression for more effective hemostatic control of uterine bleeding.

Methods: The uterine sandwich technique was used in a total of twelve patients managed in a tertiary care service hospital during caesarean deliveries. In four cases of uterine atony, the sandwich technique was used, for patients unresponsive to the conservative management. In eight patients the sandwich technique was used as a prophylactic measure, where according to the clinical profile of the patient there was high risk of PPH and where either blood was not available or availability was limited.

Results: In the four cases of uterine atony, the uterine sandwich technique was used therapeutically. All the patients were multigravidae. The period of gestation ranged from 34 weeks to 37 weeks. Average operating time was $50-60$ mts, average estimated blood loss was $1600 \mathrm{ml}$, average distension of Foleys catheter was $90 \mathrm{ml}$ and average duration of the intrauterine Foleys catheter balloon being in situ was $12 \mathrm{hrs}$. In eight patients, the sandwich technique was used as a prophylactic measure, for varied indications. In all the cases there was successful outcome. Post-operative outcome was uneventful in all the cases.

Conclusions: The uterine sandwich technique can be used either prophylactically or therapeutically for control of PPH. It is simple, safe, easy, effective and is easier to perform than internal iliac artery ligation and should be considered prior to proceeding for hysterectomy in a hemodynamically stable patient, in whom uterine conservation or fertility preservation is essential.

Keywords: B-Lynch, Uterine compression sutures, Uterine sandwich technique

\section{INTRODUCTION}

Globally uterine atony is one of the commonest form of $\mathrm{PPH}$ and results in significant maternal mortality and morbidity.As one of the quick, effective and safe interventions for control of PPH, uterine compression sutures(UCS) were introduced by Christopher B Lynch. Since then many modifications of UCS has been practised. ${ }^{1-3}$ Combination technique of external compression incorporating the UCS and internal uterine tamponade (uterine sandwich) using a Bakri balloon has been employed which applies forces to both the external as well as the internal surfaces of the myometrium. ${ }^{4}$ Since in low resource settings Bakri balloon is not available, we have used Foley's catheter (which is universally available), as a means of internal uterine tamponade. ${ }^{5}$ Since PPH results in significant maternal morbidity and mortality and at times in face of PPH refractory to 
medical management and gynaecologists in general have a poor or no exposure to internal iliac artery ligation and sometimes even after stepwise devascularisation when some degree of bleeding is present and the patient and relatives are adamant about preserving the uterus and future fertility especially in our country where the quest of a male child is paramount, a sandwich technique (after proper counselling regarding pro and cons ) can be useful as a uterine conserving and fertility preserving surgery.

\section{METHODS}

The uterine sandwich technique was used in a total of twelve patients managed in a tertiary care service hospital during caesarean deliveries. Four cases of uterine atony with ages ranging from 23 years to 29 years, who had persistent bleeding from uterine atony, unresponsive to the conservative management (uterine massage, intravenous oxytocin and methergine, intramuscular and intra uterine prostaglandin, rectal misopristol-800 micrograms) were considered eligible for the uterine sandwich technique. All were multigravidae, and one had a history of ectopic pregnancy. The period of gestation ranged from 34 weeks to 37 weeks. All the patients had placenta previa and one patient had pregnancy induced hypertension, one was a post ceasarean pregnancy, one was a known case of hypothyroidism, (these two also had twin pregnancy), and another was found positive for Antiphospholipid Antibody (APLA).

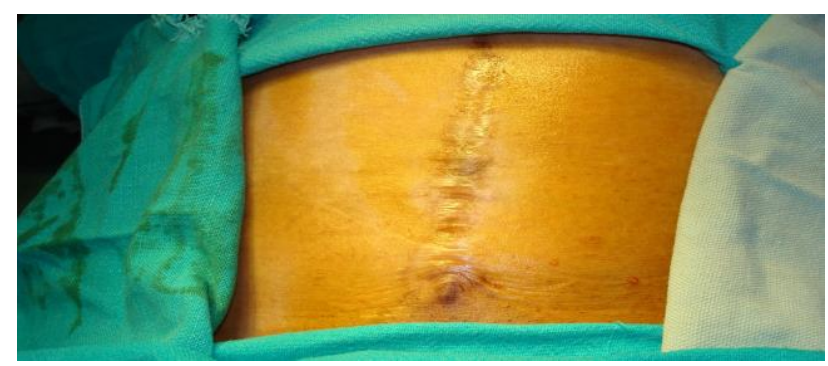

Figure 1: Post caesarean pregnancy with placenta previa.

After cleaning and draping the patient, pfannenstiel incision given, abdomen opened in layers and after delivery of the of the baby and the placenta, uterus was exteriorised.Foleys catheter no 24 , number placed varying from two to three, was placed in the uterine cavity and the lower end was passed through the cervical canal as shown in the Figure 2.

Uterine angles were sutured separately on both sides. Uterine incision was closed in a single layer using Vicryl No-1 by continous locking sutures. Routine uterotonics were given; 20 IU Oxytocin infusion in $500 \mathrm{ml}$ of saline, $0.2 \mathrm{mg}$ of Methyl ergometrine intravenous injection or 125 micrograms of Carboprost tromethamine intramuscular injection. Prophylactic antibiotics were administered while the foley's catheters were in place. An assistant manually compressed the uterus, from top- down and from side-to-side to reduce its overall size as shown in Figure 3 prior to carrying out the UCS.

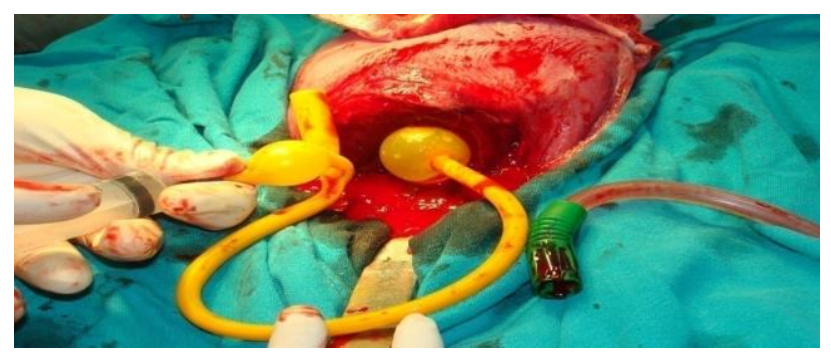

Figure 2: Intrauterine balloon placement with Foley's Catheter.

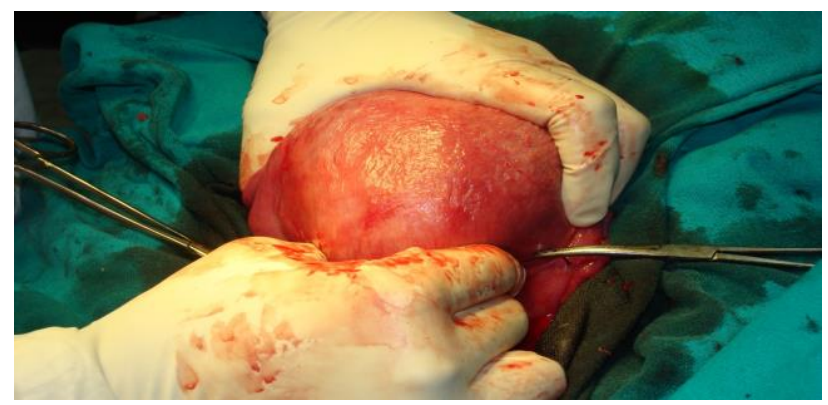

Figure 3: Manual compression of uterus before applying UCS, reduces the overall size of the uterus, prior to application of uterine compression sutures.

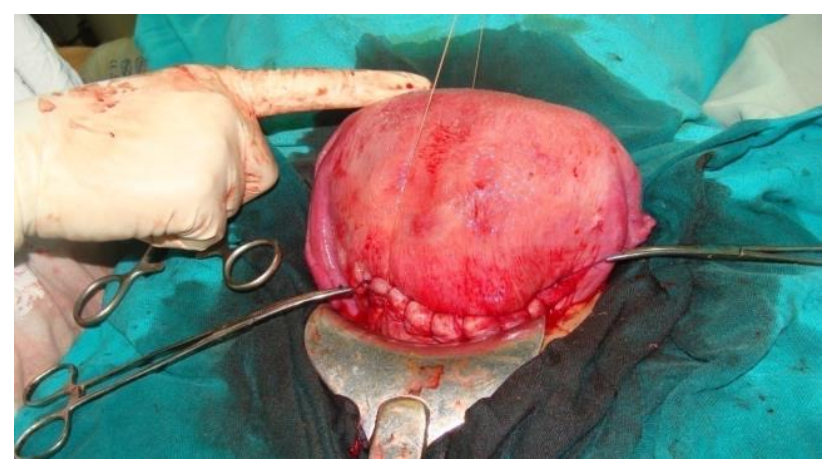

Figure 4: Uterine compression sutures being placed using the modified Hayman's Technique.

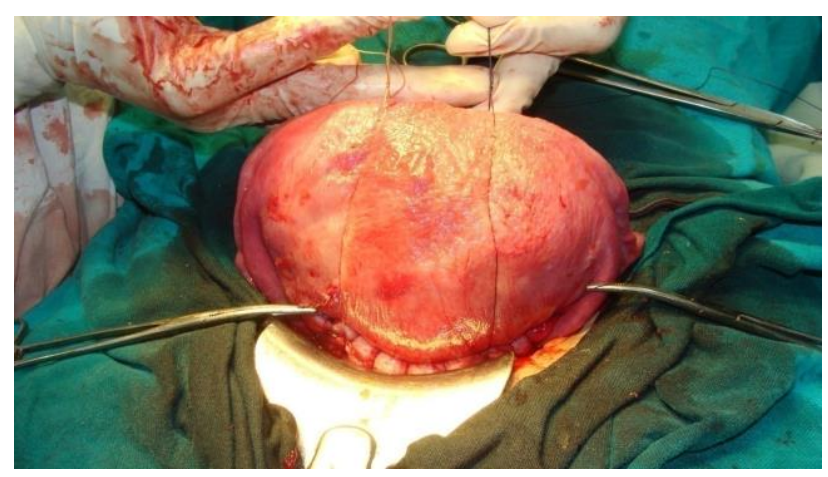

Figure 5: Two loops of compression sutures, placed on either side of the uterus. 
No-2 Chromic catgut was used to transfix the uterus from front to back, $3 \mathrm{cms}$ medial to uterine angle and $2 \mathrm{cms}$ above the sutured uterine incision and was then tied above the fundus of the uterus as shown in Figure 4.

Two such sutures were taken. The compression sutures at the fundus are placed medial to the tubal insertion site so that the tube is not damaged as shown in Figure 5.

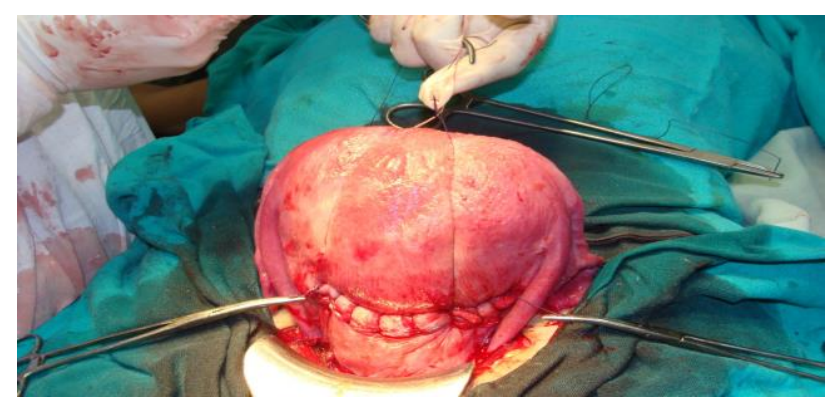

Figure 6: The two loops of sutures tied at the fundus to prevent slippage.

The two loops are tied separately at the fundus of the uterus and are then tied together to prevent slippage as shown in Figure 6.
Foley's catheters filled with normal saline while visualizing the uterine response to increasing tamponade. Insufflation was stopped with evidence of uterine distension attempting to avoid undue blanching at the compression suture sites by visual inspection. The uterine compression suture in the study is a modification of Hayman suture where No. 2 Chromic catgut suture was used. As the uterus involutes to a non pregnant size, delayed absorption sutures may result in long loops separated from the uterus that theoretically could entrap intraabdominal tissue, so No. 2 Chromic catgut suture was used in this study. After completion of the sutures abdomen was closed in layers after achieving adequate haemostasis and after verification of swab and instrument count. All patients were examined by the surgical team on daily ward rounds.. Postsurgery the patients were discharged after 7 days and called for follow up after two, four and six weeks for history,examination,along with ultrasound examination for any possible complication.

\section{RESULTS}

The obstetrical profiles of the four patients who underwent combination therapy is as below.

Table 1: Obstetrical profiles of the patients.

\begin{tabular}{|c|c|c|c|c|c|}
\hline Age & Parity & Gestation & Mode of delivery & Comorbidity & $\begin{array}{l}\text { Associated obstetrical } \\
\text { conditions }\end{array}$ \\
\hline 23 & G3P1L0A1 & $38 \mathrm{~W}$ & LSCS & Hypothyroidism & Placenta Previa \\
\hline 24 & G2P0L0 (MTP) & $37 \mathrm{~W}$ & LSCS & - & Placenta Previa \\
\hline 27 & G2P1L1 & $36 \mathrm{~W}$ & LSCS & - & Placenta Previa/PIH \\
\hline 29 & G3P1L1 (Ectopic) & $34 \mathrm{~W}$ & LSCS & APLA positive & Placenta Previa \\
\hline
\end{tabular}

Table 2: Treatment profiles of the patients.

\begin{tabular}{|lllllll|}
\hline Case & $\begin{array}{l}\text { Uterine } \\
\text { massage }\end{array}$ & $\begin{array}{l}\text { Hot } \\
\text { Compression }\end{array}$ & $\begin{array}{l}\text { Inj. } \\
\text { oxytocin }\end{array}$ & $\begin{array}{l}\text { Inj. } \\
\text { Methergin }\end{array}$ & Inj.pg & $\begin{array}{l}\text { Treatment } \\
\text { duration }\end{array}$ \\
\hline 1 & Yes & Yes & Yes & Yes & Yes & $25-30 \mathrm{~min}$ \\
\hline 2 & Yes & Yes & Yes & Yes & Yes & $15 \mathrm{~min}$ \\
\hline 3 & Yes & Yes & Yes & Yes & Yes & $25-30 \mathrm{~min}$ \\
\hline 4 & Yes & Yes & Yes & Yes & Yes & $25-30 \mathrm{~min}$ \\
\hline
\end{tabular}

Table 3: Transfusion profiles of the patients.

\begin{tabular}{|llllll|}
\hline Case & $\begin{array}{l}\text { Preoperative } \\
\text { haemoglobin }\end{array}$ & $\begin{array}{l}\text { Blood loss } \\
\text { (approximate) }\end{array}$ & $\begin{array}{l}\text { Transfusion (packed red } \\
\text { blood cells) }\end{array}$ & $\begin{array}{l}\text { Transfusion } \\
\text { (fip) }\end{array}$ & $\begin{array}{l}\text { Post transfusion } \\
\text { haemoglobin }\end{array}$ \\
\hline 1 & 9.8 & $1500 \mathrm{ml}$ & 3 units & $600 \mathrm{ml}$ & 8.2 \\
\hline 2 & 9.6 & $2000 \mathrm{ml}$ & 4 units & $800 \mathrm{ml}$ & 8.8 \\
\hline 3 & 10.4 & $1300-1500 \mathrm{ml}$ & 3 units & $600 \mathrm{ml}$ & 9.6 \\
\hline 4 & 9.2 & $1500 \mathrm{ml}$ & 3 units & $600 \mathrm{ml}$ & 8.4 \\
\hline
\end{tabular}

\section{Treatment profile of the patients}

All the four patients were managed with traditional methods of treating $\mathrm{PPH}$, i.e. uterine massage, hot compression, injections Oxytocin, Methergin, and
Prostaglandin (PG) injections. The above modalities were tried for an average period of about 20 minutes in each case, before resorting to UCS along along with intrauterine balloon tamponade (Table 2). 


\section{Transfusion profile}

The approximate amount of blood loss varied from 1300 $\mathrm{ml}$ to $1500 \mathrm{ml}$, for which the patients were given appropriate amount of whole blood and FFP to compensate for the volume loss (Table 3). The compression interventions were successful in all the four patients.

Table 4: Uterine sandwich intervention outcomes.

\begin{tabular}{|c|c|c|}
\hline Case & Intervention & $\begin{array}{l}\text { Intervention } \\
\text { outcome }\end{array}$ \\
\hline 1 & $\begin{array}{l}\text { UCS + two intrauterine Foleys } \\
\text { catheter }\end{array}$ & Successful \\
\hline 2 & $\begin{array}{l}\text { UCS +Cervical Isthmic suture }+ \\
\text { three intrauterine Foleys catheter }\end{array}$ & Successful \\
\hline 3 & $\begin{array}{l}\text { UCS + three intrauterine Foleys } \\
\text { catheter }\end{array}$ & Successful \\
\hline 4 & $\begin{array}{l}\text { UCS + two intrauterine Foleys } \\
\text { catheter }\end{array}$ & Successful \\
\hline
\end{tabular}

Four patients were managed -The combined technique was successful in all cases

Average operating time - 50- $60 \mathrm{mts}$.

Average estimated blood loss $-1600 \mathrm{ml}$.

Average distension of - $90 \mathrm{ml}$. Foleys catheter

Average duration of the intrauterine Foleys catheter balloon being in situ - $12 \mathrm{hrs}$.

Gradually the Foleys balloon insufflation was minimized to avoid excessive intrauterine pressure that may result in a uterine laceration or subsequent necrosis. The patients were then strictly monitored by members of the operating team to assess for further degree of blood loss and to assess whether any further interventions would be required.

However the four patients responded well to the combination therapy and had an uneventful postoperative period.

Table 5: Patient profile for prophylactic usage of combination technique.

\begin{tabular}{|c|c|c|c|c|}
\hline Serial no & Age of patient & Obstetrical profile & Indication For Combination Therapy & Co-morbidity \\
\hline 1 & 32 & G3 P2 L2 & $\begin{array}{l}\text { Twin Pregnancy } \\
\text { Placenta Previa }\end{array}$ & $\begin{array}{l}\text { Intrahepatic } \\
\text { Cholestasis Of } \\
\text { Pregnancy } \\
\text { Mild Dimorphic Anemia }\end{array}$ \\
\hline 2 & 30 & G4P1L1A2 & $\begin{array}{l}\text { Placenta previa } \\
\text { AB positive Blood Group }\end{array}$ & $\begin{array}{l}\text { Chronic } \\
\text { Hypertension } \\
\text { Hypothroidism }\end{array}$ \\
\hline 3 & 34 & G2P1L1 & $\begin{array}{l}\text { Post Ceasarean Pregnancy } \\
\text { Localized Placenta Accreta }\end{array}$ & $\begin{array}{l}\text { Mild Anemia } \\
\text { Gestational } \\
\text { Diabetes } \\
\text { Mellitus }\end{array}$ \\
\hline 4 & 24 & Primigravida & $\begin{array}{l}\text { Prolonged Labour } \\
\text { O Negative Blood Group }\end{array}$ & $\begin{array}{l}\text { Mild Anemia } \\
\text { Hypothroidism }\end{array}$ \\
\hline 6 & 29 & G2P1L1 & $\begin{array}{l}\text { Twin Pregnancy } \\
\text { Moderate Abruptio placentae }\end{array}$ & $\begin{array}{l}\text { Gestational } \\
\text { Diabetes } \\
\text { Mellitus } \\
\text { Hypothroidism }\end{array}$ \\
\hline 7 & 31 & G2P1L1 & $\begin{array}{l}\text { Pregnancy With } \\
\text { Fibroid Uterus }\end{array}$ & $\begin{array}{l}\text { Chronic } \\
\text { Hypertension } \\
\text { Gestational } \\
\text { Diabetes } \\
\text { Mellitus }\end{array}$ \\
\hline 8 & 26 & Primigravida & $\begin{array}{l}\text { Prolonged Labour } \\
\text { Chorioamnionitis } \\
\text { AB Negative Blood Group }\end{array}$ & $\begin{array}{l}\text { Gestational } \\
\text { Diabetes } \\
\text { Mellitus } \\
\text { Intrahepatic } \\
\text { Cholestasis Of } \\
\text { Pregnancy }\end{array}$ \\
\hline
\end{tabular}

In addition to the patients in whom indicated combination therapy was indicated, in eight patients combination therapy was used on a prophylactic basis during caesarean deliveries, based on the clinical risk assessment individually and where the risk of $\mathrm{PPH}$ was assessed to be high, prophylactic usage of the combination technique was employed. The indications were as varied as twin pregnancy, placenta previa, localized placenta accreta, 
prolonged labour, chorioamnionitis, fibroid uterus ,and moderate placental abruption. It also included patients who had independent risk factors such as mild-moderate anemia, severe intrahepatic cholestasis of pregnancy, and hypothyroidism. Also in consideration were situations in which the blood group was negative and blood was not easily available.

\section{DISCUSSION}

Since the classical B Lynch suture, various modification of B Lynch suture, were described, Hayman, Cho multiple square suture, U-Suturing Technique, Pereira sutures etc within the lower uterine segment. ${ }^{1-3}$ Combination technique of external compression and internal tamponade (uterine sandwich) which applies forces to both surfaces of the myometrium have been used. ${ }^{4}$ Various variations of techniques have been tried since PPH results in significant maternal morbidity and mortality. ${ }^{5}$

The principal indications for this procedure are patients with an atonic uterus, unresponsive to the aggressive conservative management after caesarean section or vaginal delivery, who are haemodynamically stable and who desires future reproductive capability. ${ }^{6}$ There is a reluctance to avoid hysterectomy which is a definitive treatment, especially in younger women,it is difficult to justify in cases of litigation as to why this procedure was not considered prior to a procedure which could cause permanent sterility and was associated with inherent complications.

Combination therapy is easier to perform than internal iliac artery ligation and does not need additional facilities such as interventional radiology services. This procedure can also be used prophylactically in patients at high risk of $\mathrm{PPH}$, viz multiple pregnancy, placenta praevia, localised placenta accreta, prolonged labour, chorioamnionitis etc Intrauterine balloons are effective in controlling capillary/venous bleeding and surface oozing' in cases of placenta praevia. ${ }^{7}$

Possible complications of combination therapy include excessive uterine compression resulting in uterine ischaemia or even uterine necrosis due to poor perfusion,can result in uterine lacerations, and endomyometritis. ${ }^{8}$

UCS also carries the risk of synechiae formation. ${ }^{9}$ The intrauterine balloon is believed to act by exerting in inward-to-outward pressure to control bleeding and also by exerting hydrostatic pressure on the uterine arteries. ${ }^{10}$

Overdistension of intrauterine balloon can lead to and risk of uterine laceration, necrosis or rupture. To minimize this problem, we inflated the intrauterine foleys balloon after placement of the compression suture, while assessing the myometrial response visually and also minimizing the duration of balloon being in situ.

\section{CONCLUSION}

Combination therapy is a simple, safe, easy, effective and fertility preserving procedure to control post-partum haemorrhage refractory to medical management. Combination of compression sutures with intrauterine Foleys balloons, is an effective method of preventing and treating postpartum haemorrhage.

It should be attempted as early as possible in order to maximize its success. It can be easily performed and even a junior doctor can perform it. Results with the combination technique using Foley catheters are encouraging, but further evaluation by large case series to confirm the potential advantages of this procedure and prolonged postoperative followup are required.

Funding: No funding sources

Conflict of interest: None declared

Ethical approval: The study was approved by the Institutional Ethics Committee

\section{REFERENCES}

1. Hayman RG, Arulkumaran S, Steer PJ. Uterine compression sutures: surgical management of postpartum haemorrhage. Obst Gynecol. 2002;99:502.

2. Ghezzi F1, Cromi A, Uccella S, Raio L, Bolis P, Surbek D. The Hayman technique: a simple method to treat postpartum haemorrhage. BJOG 2007;114(3):362.

3. Marasinghe JP, Condous G, Seneviratne HR, Marasinghe U. Modified anchored B-Lynch uterine compression suture for post partum bleeding with uterine atony. Acta Obstet Gynecol Scand. 2011; 90(3):280-3.

4. Yoong W, Ridout A, Memtsa M, Stavroulis A, ArefAdib M, Ramsay-Marcelle Z, et al. Application of uterine compression suture in association with intrauterine balloon tamponade ("uterine sandwich") for postpartum hemorrhage. Acta Obstet Gynecol Scand. Acta Obstet Gynecol Scand. 2012;91(1):14751.

5. WHO. Reducing the Global Burden: Postpartum Haemorrhage. Making Pregnancy Safer; 2007.

6. Fotopoulou C, Dudenhausen JW. Uterine compression sutures for preserving fertility in severe postpartum haemorrhage: an overview 13 years after the first description.J Obstet Gynaecol. 2010;30(4):339-49.

7. Bakri YN. Balloon device for control of obstetrical bleeding. Eur j Obstet Gynecol reprod Biol. 1999;86:S33-S101.

8. Joshi VM, Shrivastava M. Partial ischemic necrosis of the uterus following a uterine brace compression suture. BJOG. 2004;111:2709.

9. Poujade O, Grossetti A, Mougel L, Ceccaldi PF, Ducarme G, Luton D. Risk of synechiae following uterine compression sutures in the management of 
major postpartum haemorrhage. BJOG. 2011;118(4):433-9.

10. Cho Y, Rizvi C, Uppal T, Condous G. Ultrasonographic visualization of balloon placement for uterine tamponade in massive primary postpartum hemorrhage. Ultrasound obstet Gynecol. 2008;32:711-3.

Cite this article as: Dhillon AS, Dhillon K. Use of combination method (uterine sandwich technique) to control postpartum hemorrhage. Int J Reprod

Contracept Obstet Gynecol 2018;7:2753-8. 